\title{
Arabidopsis Regenerating Protoplast: A Powerful Model System for Combining the Proteomics of Cell Wall Proteins and the Visualization of Cell Wall Dynamics
}

\author{
Ryusuke Yokoyama, Hiroaki Kuki, Takeshi Kuroha and Kazuhiko Nishitani * \\ Laboratory of Plant Cell Wall Biology, Graduate School of Life Sciences, Tohoku University, \\ Sendai 890-8578, Japan; ryokoyama@m.tohoku.ac.jp (R.Y.); kuki@biology.tohoku.ac.jp (H.K.); \\ tkuroha@m.tohoku.ac.jp (T.K.) \\ * Correspondence: nishitan@m.tohoku.ac.jp; Tel.: +81-22-795-6700 \\ Academic Editor: Jacek R. Wisniewski \\ Received: 15 August 2016; Accepted: 4 November 2016; Published: 17 November 2016
}

\begin{abstract}
The development of a range of sub-proteomic approaches to the plant cell wall has identified many of the cell wall proteins. However, it remains difficult to elucidate the precise biological role of each protein and the cell wall dynamics driven by their actions. The plant protoplast provides an excellent means not only for characterizing cell wall proteins, but also for visualizing the dynamics of cell wall regeneration, during which cell wall proteins are secreted. It therefore offers a unique opportunity to investigate the de novo construction process of the cell wall. This review deals with sub-proteomic approaches to the plant cell wall through the use of protoplasts, a methodology that will provide the basis for further exploration of cell wall proteins and cell wall dynamics.
\end{abstract}

Keywords: protoplast; cell wall; sub-proteomics; imaging technique

\section{Introduction}

Plant cell walls are complex and dynamic cellular structures that play a critical role not only in determining cell shape, but also in developmental processes, intercellular communication and defensive responses [1-4]. One of the main features of the plant cell wall is a framework composed of cellulose microfibrils embedded in a matrix of polysaccharides, such as hemicelluloses and pectins [5-9]. However, approaches to visualizing the structural dynamics of this framework remain underdeveloped, despite its essential roles in determining the physical properties and regulating the biological functions of the cell wall. Thus, the development of a new, reliable method enabling the visualization of cell wall dynamics is a high priority of research aimed at a more refined understanding of cell wall formation, both in terms of the synthesis and integration of new polysaccharides and the assembly of the polysaccharide network.

The assembly and rearrangement of the cell wall structure are mainly achieved in muro via the actions of extracellular cell wall proteins [10]. The abundance and diversity of cell wall proteins, which account for approximately $10 \%$ of the cell wall mass, contribute to the structural and functional diversity of the cell wall [11]. Each of the complete plant genome sequences reported to date is estimated to contain at least several thousand genes encoding putative extracellular proteins [12]. Only a limited number of these extracellular proteins has so far been characterized for function, particularly regarding cell wall dynamics $[9,13]$, and thus, a full picture of how cell wall dynamics result from the concerted action of such proteins is not yet attainable.

Protoplasts isolated enzymatically from the tissues and cultured cells of plants are capable of forming new cell walls and therefore offer a unique opportunity to study various steps of cell wall 
construction de novo. We previously produced protoplasts from suspension-cultured cells of Arabidopsis and, using histochemical staining techniques and electron microscopy, observed cell wall dynamics at the cell surface during cell wall regeneration [14]. Furthermore, using two-dimensional polyacrylamide gel electrophoresis (2D PAGE) and matrix-assisted laser desorption ionization-time-of-flight/mass spectrometry (MALDI-TOF/MS), we successfully identified approximately three hundred extracellular proteins derived from regenerated protoplasts and suspension-cultured cells. In this review, we will introduce these techniques, summarize some applications involved in recent developments and, finally, discuss some open problems.

\section{Preparation of Protoplasts and Cell Wall Regeneration from Protoplasts}

The suspension-cultured Alex cell line of Arabidopsis, which was established by Mathur et al. [15], has proven highly useful for analyzing large quantities of relatively uniform Arabidopsis cells. In a previous study, we prepared protoplasts from suspension-cultured Alex cells; the protocol is available at the website (https://www.plantcellwall.jp/protocol/pdf/protocol_11.pdf) [16]. In this system, the protoplasts produce a new cell wall in a short time and also show a relatively high level of synchrony of cell wall regeneration. The merits of using protoplasts include the ability to treat cells directly with chemical reagents or cell wall enzymes, such as glycoside hydrolases; for example, protoplasts treated with 2,6-dichlorobenzonitrile (DCB), an inhibitor of cellulose synthase [17], immediately ceased synthesis of cellulose, and this was followed by changes in the expression pattern of cell wall proteins (Figure 1).

A
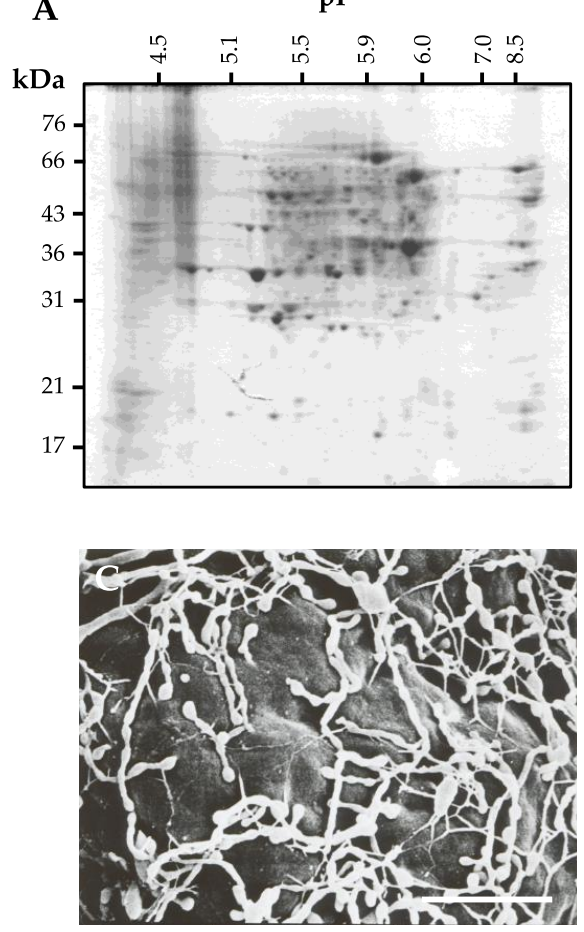

B
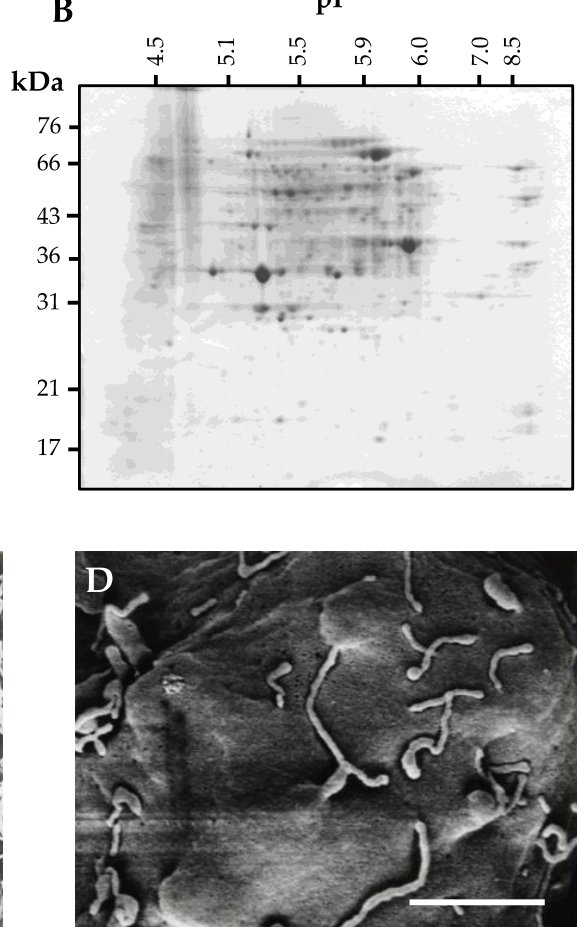

Figure 1. Comparative expression pa/erns of cell wall proteins and scanning electron microscope images of cell walls in the protoplasts regenerated for $3 \mathrm{~h}$ in the absence $(\mathbf{A}, \mathbf{C})$ or presence $(\mathbf{B}, \mathbf{D})$ of $1 \mu \mathrm{M}$ DCB. 2-D PAGE analysis of cell wall proteins from the 3-h cell-wall regenerated protoplasts (A) and the 3-h cell-wall regenerated protoplast treated with $1 \mu \mathrm{M}$ DCB (B). The cell wall proteins were prepared using the nonBdisruptive extraction with $1 \mathrm{M} \mathrm{KCl}$, and separated on a 3-10 linear pI gradient in the first dimension and visualized using Coomassie staining. Scanning electron microscope images of the protoplasts regenerated in the absence of DCB was adapted from Kwon et al. [14]. Scanning electron microscopic analysis was performed according to a similar procedure described by Kwon et al. [14]. Bar $=1.5 \mu \mathrm{m}$. 
The application of reverse genetics to the protoplast-based cell wall regeneration system also provides an attractive approach for characterizing cell wall proteins. It is not easy, however, to establish a suspension culture cell line with specific genes knocked out. We therefore recently developed an improved procedure for the regeneration of cell walls in protoplasts derived from mesophyll cells of Arabidopsis rosette leaves [18] to take advantage of T-DNA insertion lines, which are currently available for more than 20,000 genes in Arabidopsis (http://signal.salk.edu/index.html) [19]. Using this procedure, a large amount of protoplasts can easily be prepared from fully-expanded rosette leaves of three- to five-week-old Arabidopsis plants. Although the protoplasts derived from leaf mesophyll cells show slightly lower levels of synchrony of cell wall regeneration than cultured cells, the efficiency of cell wall regeneration is high, and more than $90 \%$ of protoplasts regenerate cell walls. In addition, transcriptomic analysis using microarray technology confirmed that most of the genes identified by proteomic analysis as encoding cell wall proteins in regenerating protoplasts derived from suspension-cultured Alex cells were also expressed in protoplasts derived from mesophyll (Table S1). This improved protoplast system is thus amenable to reverse genetics.

\section{Visualization of Cell Wall Dynamics in Regenerating Protoplast}

The understanding of the structural aspects of the plant cell wall has been inspired and guided by biochemical analysis. In our study, simple measurements of the sugar composition of cell walls from the protoplasts suggested gradual changes in the proportion of cell wall polysaccharides, such as pectin, with progress in regeneration (Tables S2 and S3). However, it is notoriously difficult to elucidate cell wall dynamics convincingly using only biochemical analysis (Tables S2 and S3). To gain insight into the dynamic aspects of cell wall formation, we used histochemical methods to visualize $\beta$-glucans deposited on the surface of protoplasts. Cell wall-regenerating protoplasts were stained with either Calcofluor White M2R or aniline blue, which preferentially stain cellulose and $\beta-1,3$ glucan, respectively. Both epifluorescent images were observed under a fluorescence microscope equipped with a UV fluorescence filter set (excitation filter: $350 \mathrm{~nm}$; barrier filter: $430 \mathrm{~nm}$ ). The deposition of glucans, as determined by fluorescent staining, appeared within $1 \mathrm{~h}$ of cell wall regeneration, and the extent of deposition increased and spread across the surface over $3 \mathrm{~h}$ of regeneration [14].

Recently, we examined in more detail the sequence of deposition of cellulose microfibrils in regenerating protoplasts using a confocal laser scanning microscope [18]. The protoplasts showed a random orientation of cellulose microfibrils in the early stages, followed by partially unidirectional reorientation of cellulose microfibrils. This implies that ordered cellulose deposition may be responsible for the early polarization of protoplasts and the oriented expansion of regenerated protoplasts.

Visualization of cellulose microfibrils using fluorescence staining with Calcofluor White has been performed in many plant species [20-22]. Although this procedure is simple and robust, Calcofluor White has the disadvantage of specificity for cellulose microfibril and toxic properties that might be injurious to the live cells. Recently, fluorescence staining with Pontamine Fast Scarlet 4 BS (S4B) combined with spinning disk confocal microscopy has been used successfully to observe cellulose patterning [23]. This fluorescent dye binds cellulose with high specificity and has the potential to permit the staining of living cells [24]. The S4B staining protocol may be more valuable for real-time imaging of cellulose microfibrils of living cells. These studies strongly support the hypothesis that oriented deposition of cellulose microfibrils determines the direction of cell elongation [25]. However, the dynamics of the matrix polysaccharides associated with cellulose microfibrils during the early stage of the cell wall formation remain elusive, as do the subsequent dynamics of the reorientation of the cellulose microfibrils themselves.

In addition to staining with fluorescent compounds, immunofluorescence analysis using monoclonal antibodies is a broadly useful technique for visualizing cell wall polysaccharides [26-28]. The use of a disk-shaped plasma membrane sheet, prepared by the lysis of cell wall-regenerating protoplasts in a low osmotic medium, has greatly facilitated immunofluorescence analysis of cell wall polysaccharides $[29,30]$. 
These tools have helped identify cell wall polysaccharides in regenerating protoplasts and provided new insights into the organization of polysaccharides. Further progress in integrating the dynamics of each component into a complete picture of cell wall dynamics, however, may require new approaches. Quantitative imaging is one of the most useful techniques for evaluating the configuration and dynamics of the entire cell wall (Figure 2). Visualizing the dynamics of actin microfilaments and cortical microtubules, including their elongation, severing, buckling and straightening, is important in building up a complete picture of the cell wall [31,32]. The dynamic images acquired will provide a rich source of information, leading to a precise understanding of how the spatiotemporal organization of cell wall polysaccharides is governed by an ensemble of cell wall proteins.

A

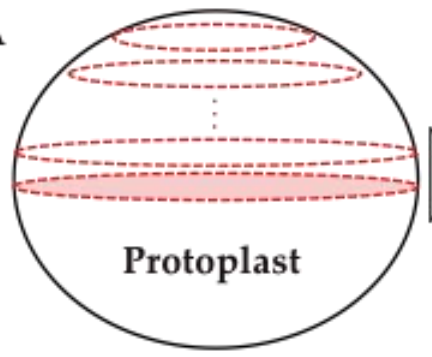

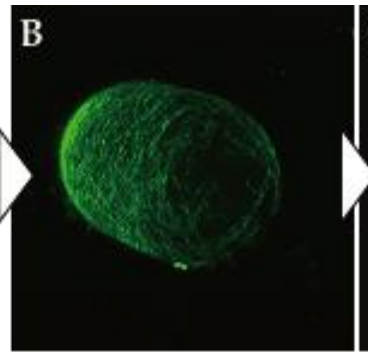

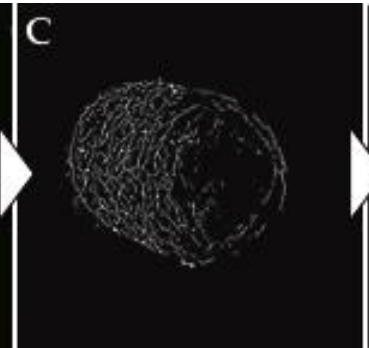

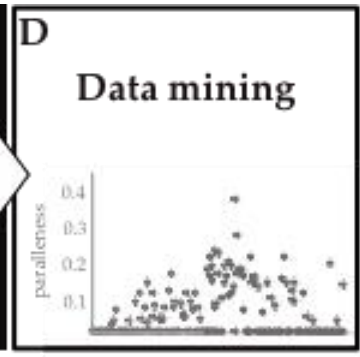

Figure 2. Schematic outline of the quantitative image analysis used in this study. (A) Histochemical or immunohistochemical staining of the cell wall components, and acquisition of serial optical image sections using confocal laser scanning microscopy; (B) Stacks of the serial optical sections; (C) Image processing and optimization; (D) Quantitative image analysis for total length, parallelness and straightening of the cell wall components.

\section{Preparation of Cell Wall Proteins}

\subsection{Conventional Extraction Procedure for Cell Wall Proteins}

The cell wall proteins loosely bound to the cell wall can be easily extracted with a series of solvents from the suspension cell culture medium and from intact cells [33,34]. In addition, the use of this non-destructive extraction procedure without disrupting cellular integrity can avoid contamination from cytoplasmic proteins. Robertson et al. [35] initially reported the systematic extraction of the cell wall proteins with a series of solvents, including aqueous solutions of $200 \mathrm{mM}$ calcium chloride, $50 \mathrm{mM}$ 1,2-cyclohexanediaminetetraacetic acid (CDTA), $2 \mathrm{mM}$ dithiothreitol (DTT), $1 \mathrm{M}$ sodium chloride and $200 \mathrm{mM}$ borate buffer. This sequential washing approach, with some modifications, has been extensively used to obtain the cell wall proteins [36,37].

Bayer et al. [38] also summarized critical paths in plant cell wall proteomics: (1) sampling of plant tissues comprised of mixtures of cell types with differing cell wall characteristics; (2) preparation in pure form of the cell wall; (3) isolation and characterization of many proteins tightly associated with the cell wall; (4) the resolving ability of 2-DE for separation of some hydrophobic and many basic proteins. In view of the above problems associated with the sampling and preparation of the cell wall proteins, the use of uniform protoplasts, which can undergo synchronized regeneration of the cell wall, has proven to be useful in obtaining highly pure protein samples at the specific stage of the cell wall formation.

\subsection{Extraction Procedure for Cell Wall Proteins from Protoplast}

Comparison of the extraction efficiency and specificity of cell wall proteins from cell wall-regenerating protoplasts between various extraction solutions indicates that the highly efficient extraction of cell wall proteins can only be achieved using an extraction solution containing $1 \mathrm{M} \mathrm{KCl}$. Glucose-6-phosphate dehydrogenase (G6PDH), a marker enzyme for contamination by cytoplasmic proteins, is used to determine the occurrence and extent of the leakage of cytosolic proteins from the 
protoplasts during the extraction processes [39]. In typical extraction experiments, the specific G6PDH activity in $1 \mathrm{M} \mathrm{KCl}$ extracts from protoplasts is less than $1 \%$ of that in cytosolic extracts.

A similar extraction method of cell wall proteins has also been used to study plant defense responses using suspension-cultured cells, to easily obtain the cell wall proteins secreted by the application of various stimuli $[40,41]$. In these studies, cell wall proteins could be extracted from the suspension-cultured cells, following the application of fungal elicitors, with calcium chloride. Thus, the use of protoplasts and cell cultures has been useful to easily obtain cell wall proteins. However, since the plasma membrane may easily be ruptured in these procedures, we should validate whether cytosolic proteins leak out of the protoplasts and the suspension-cultured cells during protein extraction processes. Today, we can use a number of different types of cytosolic markers [42] and discriminate between intracellular and extracellular proteins through bio-informatics analyses $[43,44]$.

\subsection{Problem of the Extraction Procedure for Cell Wall Proteins}

Although the non-destructive solvent extraction approach is very useful for obtaining cell wall proteins without contamination, it may not be a satisfactory method for the comprehensive identification of all cell wall proteins. Some proteins are tightly linked to the cell wall architecture, even in the early stages of cell wall regeneration in protoplasts, and others are anchored to the plasma membrane. To overcome these problems, intrinsic to proteins tightly bound to the cell wall, modified series of solvents have been successfully used for non-destructive extraction $[33,45,46]$. Another problem intrinsic to the non-destructive extraction of proteins from protoplasts at early stages of cell wall regeneration is contamination with cytosolic proteins due to the rupture of the plasma membrane during sample handling [33,47].

\subsection{Cell Wall Protein Purification Techniques}

Some disruptive purification approaches coupled with a specific recovery procedure for cell wall proteins may produce a more comprehensive sample of isolated cell wall proteins. For example, $\mathrm{N}$-glycosylation is a common post-translational modification for proteins trafficking through the secretory pathway, and therefore, most cell wall proteins are thought to be glycosylated in the apoplast [48-50]. For this reason, lectin-based affinity chromatography appears a promising method for obtaining cell wall proteins from a crude protein extract. More than one hundred glycoproteins were isolated from mature stems of Arabidopsis thaliana by affinity chromatography using Concanavalin A Sepharose [51]. Fluid-phase partitioning methods have also been widely used to isolate cell wall-related proteins, such as glycosylphosphatidyl inositol-anchored proteins (GAPs) and membrane proteins [52-55]. Finally, one of the most widely-available approaches is the extraction of proteins from a cell wall fraction, which has been separated from cell homogenates [56]. This approach has been further developed to enable the extraction of cell wall proteins with differing degrees of affinity to the cell wall fraction $[57,58]$. In Saccharomyces cerevisiae and other fungi, the extraction of proteins tightly bound to the cell wall has been achieved by enzymatic digestion of the isolated cell wall fraction [59-61]. Such an enzymatic digestion can also be applied to the extraction of cell wall proteins from plant cell homogenates.

\subsection{Improved Extraction Procedure for Cell Wall Protein from Protoplasts}

In general, a complete cell wall proteome cannot be obtained using a single protocol. Thus, to increase the efficiency of the extraction of cell wall proteins from protoplasts, it may be necessary to use a combination of non-destructive and disruptive procedures. One challenge to our sub-proteomic approach is the application of enzymatic digestion techniques to the non-disruptive method of extraction. By using enzymes capable of degrading cell wall polysaccharides, we sought to isolate proteins that were tightly associated with the cell wall from intact protoplasts. Although additional cell wall proteins could be isolated by this procedure, a decrease in cellular integrity caused by enzyme 
treatment may cause contamination with intracellular proteins. We need to further investigate the optimum enzymatic digestion technique to avoid contamination.

\section{Protein Separation and Mass Spectrometry for Identification}

In our study, cell wall proteins were separated by 2D PAGE using immobilized isoelectric point gradient strips (pI 3-10 and $\mathrm{pI}$ 6-11) for the first dimension separation and 12\% SDS-PAGE for the second separation. After staining with coomassie brilliant blue (CBB) to visualize the protein spots, we mapped each protein in the 2D gels using Image Master 2D-Elite software (Amersham Pharmacia Biotech, Buckinghamshire, UK, v4.01). Individual protein spots were picked and in-gel digested with trypsin, and protein sequences and genes encoding the proteins were identified using MALDI-TOF/MS analysis coupled with a database search using the Mascot sequence database search program (Matrix Science, Boston, MA, USA). As a result, 108 protein spots were identified from protoplasts regenerated for $1 \mathrm{~h}$ and 116 spots from those regenerated for $3 \mathrm{~h}$, while 55 protein spots were identified from the suspension-cultured Alex cells [14]. The identified proteins were classified according to the predicted families of the cell-wall related proteins [62] and other families, including proteases, esterases, kinases and oxidoreductases.

In our experiment, some spots in the 2D gels resulted in frustrated attempts to identify the corresponding protein by the peptide mass mapping using MALDI-TOF/MS. There are useful complements to this standard procedure. An alternative to the peptide mass mapping using MALDI-TOF/MS is de novo sequencing by electrospray ionization tandem mass spectrometry (ESI)-MS/MS. ESI-MS/MS yields amino acid sequences of the separated peptides, allowing more definitive identification of the protein [47]. The additional level of separation offered by liquid chromatography is thought to have several advantages for the increased resolving of the digested peptides. Additionally, recently, a method for the pre-fractionation of proteins previous to LC, such as a filter-aided sample preparation (FASP), may facilitate accurate mass spectrometers [63]. Thus, liquid chromatography coupled with tandem mass spectrometry (LC-MS/MS) may become one of the essential tools in our proteomic analysis.

There are also some problems particular to the cell wall proteins in the cell wall proteomics approach. For example, arabinogalactan proteins (AGPs), in which up to $90 \%$ of the polysaccharides are linked to the protein by $O$-glycosylation, are not revealed by staining with $\mathrm{CBB}$ and are instead recognized by the $\beta$-glucosyl Yariv reagent [64]. Identification of proteoglycans with high O-glycosylation, such as AGPs, requires deglycosylation prior to digestion with trypsin; anhydrous hydrogen fluoride treatment can be used for chemical deglycosylation of AGPs [65]. Additionally, recent progress in pre-fractionation of proteins may also be useful for identifying some particular cell wall proteins. Multidimensional Protein Identification Technology (MudPIT) is a good example of peptide pre-fractionation methods and can be used to resolve peptide mixtures prior to LC-MS analysis [66]. 2D PAGE analysis followed by peptide mass mapping using MALDI-TOF/MS is the simplest approach for the comparative identification of proteins in proteomic analysis. Its combination with additional techniques for specific applications may increase the coverage and accuracy of cell wall proteomics.

The Arabidopsis cell wall proteins, which are identified by means of proteomics, can be characterized by The Arabidopsis Information Resource (TAIR; http:/ /arabidopsis.org). Although the biological functions of many of these proteins identified a decade ago have not yet been determined [14], recent progress in Arabidopsis genes has begun to shed light on the functions of these proteins. A good example is the characterization of AtMSR2 (At1g51630), which was annotated as an "unknown" gene in 2005 [14] and was recently demonstrated to be involved in the biosynthesis of galactomannan [67]. Table 1 summarizes the genes encoding carbohydrate-related enzymes whose functions have been re-characterized based on the recent studies. 
Table 1. Carbohydrate-related proteins in the regenerating protoplasts and suspension-cultured cells.

\begin{tabular}{|c|c|c|c|c|c|c|c|}
\hline Family * & AGI & Description ** & Protein Name & $1 \mathrm{~h}$ & $2 \mathrm{~h}$ & Native & References \\
\hline GH1 & At1g66280 & $\beta$-Glucosidase & Bglu22 & + & + & & \\
\hline GH1 & At2g44450 & $\beta$-Glucosidase & Bglu15 & & & + & \\
\hline GH1 & At3g09260 & $\beta$-Glucosidase & Bglu23/PYK10 & & + & & Ogasawara et al., 2009 [68] \\
\hline GH3 & At5g20950 & $\beta$-Xylosidase & & + & + & + & \\
\hline GH9 & At1g71380 & $\beta-1,4$-Glucanase & CEL3 & & & + & Lewis et al., 2013 [69] \\
\hline GH16 & At3g48580 & $\begin{array}{c}\text { Xyloglucan } \\
\text { endotransglucosylase/hydrolase }\end{array}$ & XTH11 & + & + & + & Yokoyama et al., 2010 [70] \\
\hline GH18 & At5g24090 & Chitinase & CHIA & & & + & Takenaka et al., 2009 [71] \\
\hline GH19 & At2g43610 & Chitinase & & + & & & \\
\hline GH27 & At5g08380 & $\alpha$-Galactosidase & AGAL1 & + & + & + & \\
\hline GH28 & At5g41870 & Polygalacturonase & & & & + & Cao, 2012 [72] \\
\hline GH28 & At5g06860 & Polygalacturonase & PGIP1 & & & + & Ferrari et al., 2012 [73] \\
\hline GH31 & At1g68560 & $\alpha$-Xylosidase & $\mathrm{AXY} 3 / \mathrm{XYL1}$ & + & + & + & Günl and Pauly, 2011 [74] \\
\hline GH32 & At3g13790 & $\beta$-Fructosidase & CWI & + & + & + & Mazola et al., 2015 [75] \\
\hline GH35 & At5g63810 & $\beta$-Galactosidase & BGAL10 & + & + & + & Sampedro et al., 2012 [76] \\
\hline GH38 & At3g26720 & $\alpha$-Mannosidase & & + & + & + & \\
\hline EXP & At3g45970 & Expansin & EXPL1 & & & + & \\
\hline
\end{tabular}

In the TAIR database, however, there are still many cell wall proteins, which have no experimentally-defined function. Although it is difficult to elucidate the precise enzymatic function and biological role of each cell wall protein in muro, in silico analysis may generate a more comprehensive catalog of the cell wall proteins. The ATTED-II database (http:/ /atted.jp/) of genes co-expressed in Arabidopsis is used to identify potential interactions among the list of the target genes [78,79]. If there are well-characterized proteins in a network of the target genes, knowledge of the well-characterized proteins can be useful for the subsequent assignment of function to the other unknown proteins in an interaction network. Furthermore, an empirically-determined protein-protein interaction database will facilitate the functional characterization of the unknown proteins [80]. In our study, we filtered the associated genes, which were identified in the regenerating protoplasts, through the ATTED-II co-expression database and constructed a large network (Figure S2). The enriched Gene Ontology (GO) terms for the large network included 'cell wall' (GO:0005618, $p$-value' $=1.3 \times 10^{-17}$ ) and 'carbohydrate metabolic process' (GO: 0005975, $p$-value $=2.2 \times 10^{-17}$ ). In the network, we could find the well-characterized genes involved in the metabolism of cell wall polysaccharides, such as xyloglucan.

\section{Xyloglucan Metabolism in Regenerating Protoplasts}

Xyloglucan is the major hemicellulose for forming a basic framework of the cell wall. We focused on the elucidation of linking the identified proteins involved in xyloglucan metabolism during early stages of cell wall regeneration. AtXTH11 (At3g48580) has been identified as a member of the endotransglucosylase/hydrolase (XTH) family of proteins [81-83], which can mediate splitting and/or reconnection of xyloglucan crosslinks [84-88]. This enzyme was present in both cell wall-regenerating protoplasts and suspension culture cells, implying that the metabolism of xyloglucan molecules is involved in cell walls.

AtXYL1 (At1g68560) and BGAL10 (At5g63810) have been confirmed as chiefly responsible for xyloglucan $\alpha$-xylosidase activity and xyloglucan $\beta$-galactosidase activity, respectively $[74,76,89]$. Several potentially phosphorylated protein spots on the 2D polyacrylamide gel were identified as AtXYL1 by staining with Pro-Q Diamond dye (Molecular Probes, Eugene, OR, USA), and thus, this protein was predicted to undergo extensive post-translational modification [14]. Recent studies showed that dephosphorylation by purple acid phosphatase (PAP) decreased the activity levels of xyloglucan $\alpha$-xylosidase, subsequently increasing the levels of xyloglucan oligosaccharides [90]. We confirmed that PAP1 (At1g13750) appears in both protoplasts regenerated for $1 \mathrm{~h}$ and in suspension culture cells, but not in protoplasts regenerated for $3 \mathrm{~h}$. It should be noted that xyloglucan 
oligosaccharides, which are potential substrates of xyloglucan $\alpha$-xylosidase and $\mathrm{XTH}$, are incorporated into the cell plate and involved in the construction of the new cell wall, thereby promoting cell division, as well as cell expansion [91,92]. In addition, XTH itself is found not only in expanding tissues [93], but also in the cell plate during the construction of the new cell wall $[94,95]$. All of these observations suggest that the metabolism of xyloglucan molecules contributes considerably to the early construction of the cell wall in regenerating protoplasts.

The presence of xyloglucan molecules in the cell plate has been reported in earlier studies [96-98]. On the other hand, our analysis of the immune-disk recently showed that xyloglucan molecules stick to cellulose microfibrils at a very early stage of cell wall regeneration in protoplasts (Figure S1). Further imaging analysis, combined with reverse genetics, will provide new insights into the biological function of xyloglucan-related enzymes and, particularly, how xyloglucan molecules are modified and how the xyloglucan/cellulose networks are assembled during the early stages of cell wall construction.

\section{Concluding Remarks}

A wide range of cell wall proteomic approaches have been developed, leading to our current understanding of plant cell walls [99-101]. These approaches have been complemented by the availability of an advanced database (WallProtDB; http://www.polebio.lrsv.ups-tlse.fr/WallProtDB/) [102]. Arabidopsis cell wall proteins, identified by means of proteomics, can also be characterized using The Arabidopsis Information Resource (TAIR; http://arabidopsis.org). In addition, the ATTED-II database (http://atted.jp/) of co-expressed genes in Arabidopsis may be used to identify potential interactions between genes [94,95]. We filtered the genes encoding proteins for a putative secretory signal peptide, which were identified in the regenerating protoplasts, through the ATTED-II co-expression database and constructed a large network (Figure S2). The enriched GO terms for this network included "cell wall" and "carbohydrate metabolic process". Although a combination of proteomic approaches and in silico analysis is generating a more comprehensive catalog of cell wall proteins, it remains difficult to elucidate the precise enzymatic function and biological role of each protein in muro.

Protoplasts are a useful model system for the comprehensive identification of cell wall proteins and for visualizing cell wall dynamics. Further progress in integrating reverse genetics into this approach will greatly facilitate the assignment of precise biological roles to these proteins and a better understanding of cell wall dynamics (Figure 3).

Finally, the recent extensive availability of complete genome sequences, and subsequent integrated omics analyses, will allow this protoplast system to be applied to other plant species. The diversity of cell wall composition and structure between plant species is well known [103-106]; as, for example, cell walls of commelinoid monocots, such as rice (Oryza sativa), contain relatively little xyloglucan and instead include a large amount of glucuronoarabinoxylan $[2,107,108]$. We have already developed an imaging technique for rice protoplasts and clarified some differences in the pattern of cellulose deposition (unpublished). Application of the protoplast system will provide new insights into the significant differences in cell wall dynamics between plant species. 


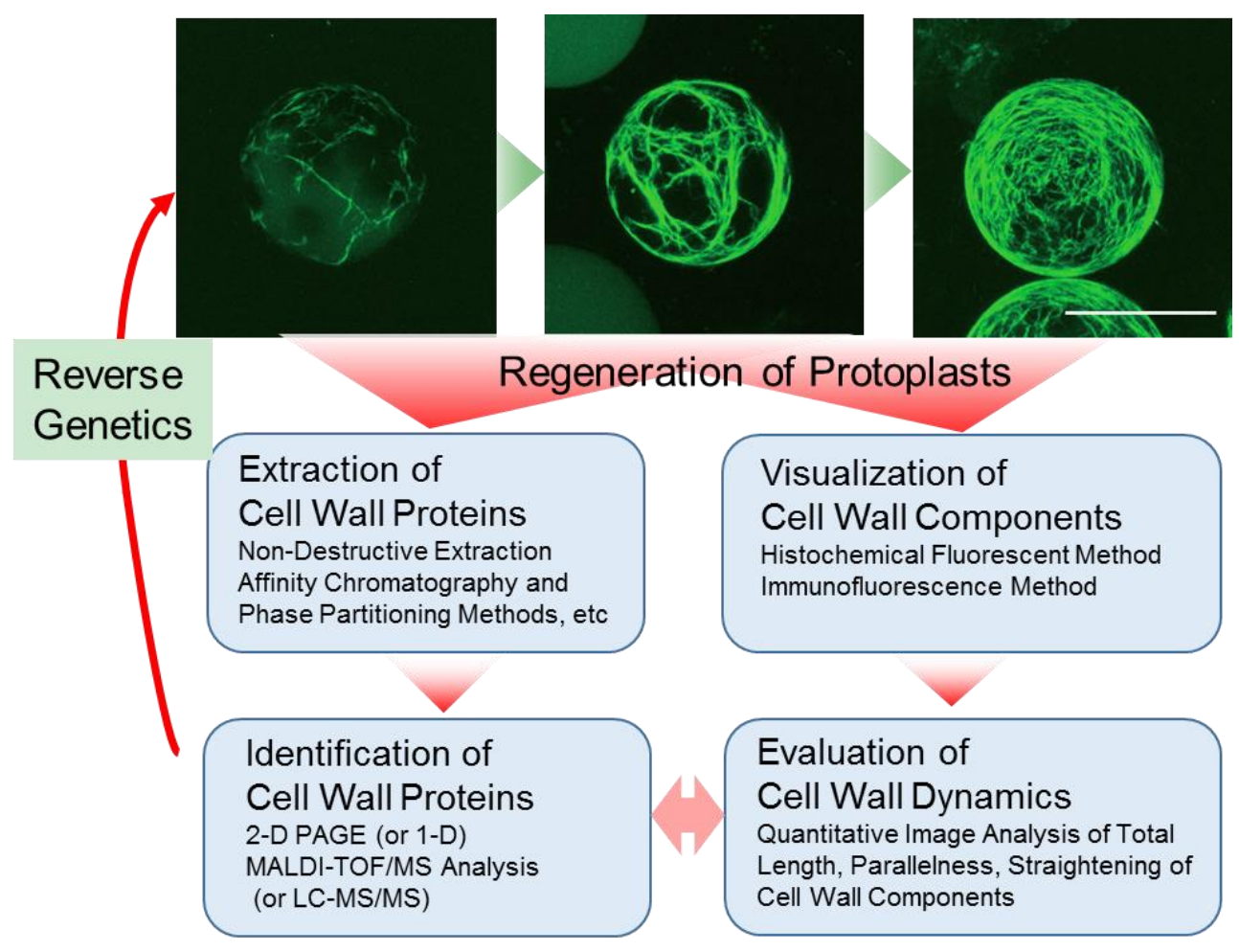

Figure 3. Strategies of cell wall sub-proteomic approaches of the cell wall, combined with the quantitative imaging technique and reverse genetics, using Arabidopsis mesophyll protoplast. Two approaches result in the comprehensive identification of the cell wall proteins and visualization of cell wall dynamics in the same stages of the protoplasts, leading to the prediction of the relationship between cell wall dynamics and the actions of the cell wall proteins. Furthermore, by use of the protoplasts derived from the T-DNA-insertion line, in which a certain gene of interest is disrupted, quantitative imaging analysis of cell wall regeneration would facilitate the identification of cell wall-related genes responsible for cell wall dynamics and help assign the precise biological role to the gene product.

Supplementary Materials: The following are available online at www.mdpi.com/2227-7382/4/4/34/s1: Table S1: Comparison of cell wall proteins of protoplasts derived from suspension-cultured cells and mesophyll cells in Arabidopsis; Table S2: Composition of the supernatant collected after every extraction step of the cell wall preparation; Table S3: Proportion of monosaccharides in the pectin fraction; Figure S1: Localization of xyloglucan molecules and $\beta$-glucan on plasma membrane sheets of the regenerating protoplasts; Figure S2: The co-expression network of the genes identified in the regenerating protoplasts.

Acknowledgments: This study was supported by the Ministry of Education, Culture, Sports, Science and Technology (MEXT, Japan), Grant-in-Aid for Scientific Research on Innovative Areas "Plant Cell Wall" (Nos. 24114001 and 24114005) to K.N. and a Grant-in-Aid for Scientific Research (C) (16K07389) to R.Y.

Author Contributions: R.Y. and K.N. conceived of and planned this review article and wrote the manuscript. H.K. contributed to experiments in Table 1, Figures 2 and 3, with occasional discussion with R.Y., T.K. and K.N. T.K. commented on the manuscript.

Conflicts of Interest: The authors declare no conflict of interest.

\section{References}

1. Somerville, C.; Bauer, S.; Brininstool, G.; Facette, M.; Hamann, T.; Milne, J.; Osborne, E.; Paredez, A.; Persson, S.; Raab, T.; et al. Toward a systems approach to understanding plant cell walls. Science 2004, 306, 2206-2211. [CrossRef] [PubMed]

2. Le Gall, H.; Philippe, F.; Domon, J.M.; Gillet, F.; Pelloux, J.; Rayon, C. Cell wall metabolism in response to abiotic stress. Plants 2015, 16, 112-166. [CrossRef] [PubMed] 
3. Bethke, G.; Thao, A.; Xiong, G.; Li, B.; Soltis, N.E.; Hatsugai, N.; Hillmer, R.A.; Katagiri, F.; Kliebenstein, D.J.; Pauly, M.; Glazebrook, J. Pectin biosynthesis is critical for cell wall integrity and immunity in Arabidopsis thaliana. Plant Cell 2016, 28, 537-556. [CrossRef] [PubMed]

4. Bidhendi, A.J.; Geitmann, A. Relating the mechanics of the primary plant cell wall to morphogenesis. J. Exp. Bot. 2016, 67, 449-461. [CrossRef] [PubMed]

5. Carpita, N.C.; Gibeaut, D.M. Structural models of primary cell walls in flowering plants: Consistency of molecular structure with the physical properties of the walls during growth. Plant J. 1993, 3, 1-30. [CrossRef] [PubMed]

6. Cosgrove, D.J. Growth of the plant cell wall. Nature Reviews: Mol. Cell Biol. 2005, 6, 850-861. [CrossRef] [PubMed]

7. Caffall, K.H.; Mohnen, D. The structure, function, and biosynthesis of plant cell wall pectic polysaccharides. Carbohydr. Res. 2009, 344, 1879-1900. [CrossRef] [PubMed]

8. Scheller, H.V.; Ulvskov, P. Hemicelluloses. Annu. Rev. Plant Biol. 2010, 61, 263-289. [CrossRef] [PubMed]

9. Cosgrove, D.J. Plant cell wall extensibility: Connecting plant cell growth with cell wall structure, mechanics and the action of wall-modifying enzymes. J. Exp. Bot. 2016, 67, 463-476. [CrossRef] [PubMed]

10. Yokoyama, R.; Shinohara, N.; Asaoka, R.; Narukawa, H.; Nishitani, K. The biosynthesis and function of polysaccharide components of the plant cell wall. In Plant Cell Wall Patterning and Cell Shape; Fukuda, H., Ed.; John Wiley \& Sons, Ltd.: Chichester, UK, 2015; pp. 3-34. [CrossRef]

11. Jamet, E.; Canut, H.; Boudart, G.; Pont-Lezica, R.F. Cell wall proteins: A new insight through proteomics. Trends Plant Sci. 2006, 1, 33-39. [CrossRef] [PubMed]

12. Goodstein, D.M.; Shu, S.; Howson, R.; Neupane, R.; Richard, D.; Hayes, R.D.; Mitros, T.; Dirks, W.; Hellsten, U.; Putnam, N.; et al. Phytozome: A comparative platform for green plant genomics. Nucleic Acids Res. 2012, 40, D1178-D1186. [CrossRef] [PubMed]

13. Voxeur, A.; Höfte, H. Cell wall integrity signaling in plants: "To grow or not to grow that's the question". Glycobiology 2016, 26, 950-960. [CrossRef] [PubMed]

14. Kwon, H.-K.; Yokoyama, R.; Nishitani, K. A proteomic approach to apoplastic proteins involved in cell wall regeneration in protoplasts of Arabidopsis suspension-cultured cells. Plant Cell Physiol. 2005, 46, 843-857. [CrossRef] [PubMed]

15. Mathur, J.; Szabados, L.; Schaefer, S.; Grunenberg, B.; Lossow, A.; Jonas-Straube, E.; Schell, J.; Koncz, C.; Koncz-Kalman, Z. Gene identification with sequenced T-DNA tags generated by transformation of Arabidopsis cell suspension. Plant J. 1998, 13, 707-716. [CrossRef] [PubMed]

16. The Plant Cell Wall Biology Laboratory, Tohoku University. Protoplastl Isolation and Cell Wall Regeneration. Available online: https://www.plantcellwall.jp/protocol/pdf/protocol_11.pdf (accessed on 15 November 2016).

17. DeBolt, S.; Gutierrez, R.; Ehrhardt, D.W.; Somerville, C. Nonmotile cellulose synthase subunits repeatedly accumulate within localized regions at the plasma membrane in Arabidopsis hypocotyl cells following 2,6-dichlorobenzonitrile treatment. Plant Physiol. 2007, 145, 334-338. [CrossRef] [PubMed]

18. Kuki, H.; Higaki, T.; Yokoyama, R.; Nishitani, K.; Tohoku University, Sendai, Japan. Unpublished work, 2016.

19. Alonso, J.M.; Stepanova, A.N.; Leisse, T.J.; Kim, C.J.; Chen, H.; Shinn, P.; Stevenson, D.K.; Zimmerman, J.; Barajas, P.; Cheuk, R.; et al. Genome-wide insertional mutagenesis of Arabidopsis thaliana. Science 2003, 301, 653-657. [CrossRef] [PubMed]

20. Nagata, T.; Takebe, I. Cell wall regeneration and cell division in isolated tobacco mesophyll protoplasts. Planta 1970, 92, 301-308. [CrossRef] [PubMed]

21. Hahne, G.; Hert, W.; Hoffmann, F. Wall formation and cell division in fluorescence-labelled plant protoplasts. Protoplasma 1983, 115, 217-221. [CrossRef]

22. Van Amstel, T.N.M.; Kengen, H.M.P. Callose deposition in the primary wall of suspension cells and regenerating protoplasts, and its relationship to patterned cellulose synthesis. Can. J. Bot. 1996, 74, 1040-1049. [CrossRef]

23. Anderson, C.T.; Carroll, A.; Akhmetova, L.; Somerville, C. Real-time imaging of cellulose reorientation during cell wall expansion in Arabidopsis roots. Plant Physiol. 2010, 152, 787-796. [CrossRef] [PubMed]

24. Liesche, J.; Ziomkiewicz, I.; Alexander Schulz, A. Super-resolution imaging with Pontamine Fast Scarlet 4BS enables direct visualization of cellulose orientation and cell connection architecture in onion epidermis cells. BMC Plant Biol. 2013, 13, 226. [CrossRef] [PubMed] 
25. Baskin, T.I. Anisotropic expansion of the plant cell wall. Ann. Rev. Cell Dev. Biol. 2005, 21, 203-222. [CrossRef] [PubMed]

26. Knox, J.P. The use of antibodies to study the architecture and developmental regulation of plant cell walls. Int. Rev. Cytol. 1997, 171, 79-120. [CrossRef] [PubMed]

27. Moller, I.; Marcus, S.E.; Haeger, A.; Verhertbruggen, Y.; Verhoef, R.; Schols, H.; Ulvskov, P.; Mikkelsen, J.D.; Knox, J.P.; Willats, W. High-throughput screening of monoclonal antibodies against plant cell wall glycans by hierarchical clustering of their carbohydrate microarray binding profiles. Glycoconj. J. 2008, 25, 37-48. [CrossRef] [PubMed]

28. Pattathil, S.; Avci, U.; Baldwin, D.; Swennes, A.G.; McGill, J.A.; Popper, Z.; Bootten, T.; Albert, A.; Davis, R.H.; Chennareddy, C.; et al. A comprehensive toolkit of plant cell wall glycan-directed monoclonal antibodies. Plant Physiol. 2010, 153, 514-525. [CrossRef] [PubMed]

29. Hirai, N.; Sonobe, S.; Hayashi, T. In situ synthesis of $\beta$-glucan microfibrils on tobacco plasma membrane sheets. Proc. Natl. Acad. Sci. USA 1998, 95, 15102-15106. [CrossRef] [PubMed]

30. Kaida, R.; Satoh, Y.; Bulone, V.; Yamada, Y.; Kaku, T.; Hayashi, T.; Kaneko, T.S. Activation of $\beta$-glucan synthases by wall-bound purple acid phosphatase in tobacco cells. Plant Physiol. 2009, 150, 1822-1830. [CrossRef] [PubMed]

31. Higaki, T.; Sano, T.; Hasezawa, S. Actin microfilament dynamics and actin side-binding proteins in plants. Curr. Opin. Plant Biol. 2007, 10, 549-556. [CrossRef] [PubMed]

32. Wasteneys, G.O.; Ambrose, J.C. Spatial organization of plant cortical microtubules: Close encounters of the 2D kind. Trends Cell Biol. 2009, 19, 62-71. [CrossRef] [PubMed]

33. Lee, S.J.; Saravanan, R.S.; Damasceno, C.M.B.; Yamane, H.; Kim, B.D.; Rose, J.K.C. Digging deeper into the plant cell wall proteome. Plant Physiol. Biochem. 2004, 42, 979-988. [CrossRef] [PubMed]

34. Jamet, E.; Albenne, C.; Boudart, G.; Irshad, M.; Canut, H.; Pont-Lezica, R. Recent advances in plant cell wall proteomics. Proteomics 2008, 8, 893-908. [CrossRef] [PubMed]

35. Robertson, D.; Mitchell, G.P.; Gilroy, J.S.; Gerrish, C.; Bolwell, G.P.; Slabas, A.R. Differential extraction and protein sequencing reveals major differences in patterns of primary cell wall proteins from plants. J. Biol. Chem. 1997, 272, 15841-15848. [CrossRef] [PubMed]

36. Boudart, G.; Jamet, E.; Rossignol, M.; Lafitte, C.; Borderies, G.; Jauneau, A.; Esquerré-Tugayé, M.T.; Pont-Lezica, R. Cell wall proteins in apoplastic fluids of Arabidopsis thaliana rosettes: Identification by mass spectrometry and bioinformatics. Proteomics 2005, 5, 212-221. [CrossRef] [PubMed]

37. Printz, B.; Morais, R.D.S.; Wienkoop, S.; Sergeant, K.; Stanley Lutts, S.; Hausman, J.-F.; Renaut, J. An improved protocol to study the plant cell wall proteome. Front. Plant Sci. 2015, 6, 237. [CrossRef] [PubMed]

38. Bayer, E.M.; Bottrill, A.R.; Walshaw, J.; Vigouroux, M.; Naldrett, M.J.; Thomas, C.L.; Maule, A.J. Arabidopsis cell wall proteome defined using multidimensional protein identification technology. Proteomics 2006, 6, 301-311. [CrossRef] [PubMed]

39. Li, Z.C.; McClure, J.W.; Hagerman, A.E. Soluble and bound apoplastic activity for peroxidase, $\beta$-D-glucosidase, malate dehydrogenase, and nonspecific arylesterase, in barly (Hordeum vulgare L.) and oat (Avena sativa L.) primary leaves. Plant Physiol. 1989, 90, 185-190. [CrossRef] [PubMed]

40. Chivasa, S.; Ndimba, B.K.; Simon, W.J.; Robertson, D.; Yu, X.-L.; Knox, J.P.; Bolwell, P.; Slabas, A.R. Proteomic analysis of the Arabidopsis thaliana cell wall. Electrophoresis 2002, 23, 1754-1765. [CrossRef]

41. Ndimba, B.K.; Chivasa, S.; Hamilton, J.M.; Simon, W.J.; Slabas, A.R. Proteomic analysis of changes in the extracellular matrix of Arabidopsis cell suspension cultures induced by fungal elicitors. Proteomics 2003, 3, 1047-1059. [CrossRef] [PubMed]

42. Cho, W.K.; Hyun, T.K.; Kumar, D.; Rim, Y.; Chen, X.Y.; Jo, Y.; Kim, S.; Lee, K.W.; Park, Z-Y.; Lucas, W.J.; Kim, J-Y. Proteomic analysis to identify tightly-bound cell wall protein in Rice calli. Mol. Cells 2015, 38, 685-696. [CrossRef] [PubMed]

43. Horton, P.; Park, K.J.; Obayashi, T.; Fujita, N.; Harada, H.; Adams-Collier, C.J.; Nakai, K. WoLF PSORT: Protein localization predictor. Nucleic Acids Res. 2007, 35, W485-W487. [CrossRef] [PubMed]

44. Emanuelsson, O.; Nielsen, H.; Brunak, S.; von Heijne, G. Predicting subcellular localization of proteins based on their N-terminal amino acid sequence. J. Mol. Biol. 2000, 300, 1005-1016. [CrossRef] [PubMed] 
45. Watson, B.S.; Lei, Z.; Dixon, R.A.; Sumner, L.W. Proteomics of Medicago sativa cell walls. Phytochemistry 2004, 65, 1709-1720. [CrossRef] [PubMed]

46. Charmont, S.; Jamet, E.; Pont-Lezica, R.; Canut, H. Proteomic analysis of secreted proteins from Arabidopsis thaliana seedlings: Improved recovery following removal of phenolic compounds. Phytochemistry 2005, 66, 453-461. [CrossRef] [PubMed]

47. Rose, J.K.C.; Bashir, S.; Giovannoni, J.J.; Jahn, M.M.; Saravanan, R.S. Tackling the plant proteome: Practical approaches, hurdles and experimental tools. Plant J. 2004, 39, 715-733. [CrossRef] [PubMed]

48. Catalá, C.; Howe, K.; Hucko, S.; Rose, J.K.C.; Thannhauser, T. Towards characterization of the glycoproteome of tomato (Solanum lycopersicum) fruit using Concanavalin A lectin affinity chromatography and LC-MALDI-MS/MS analysis. Proteomics 2011, 11, 1530-1544. [CrossRef]

49. Zhang, Y.; Giboulot, A.; Zivy, M.; Valot, B.; Jamet, E.; Albenne, C. Combining various strategies to increase the coverage of the plant cell wall glycoproteome. Phytochemistry 2011, 72, 1109-1123. [CrossRef] [PubMed]

50. Kumar, S.; Kumar, K.; Pandey, P.; Rajamani, V.; Padmalatha, K.; Dhandapani, G.; Kanakachari, M.; Leelavathi, S.; Kumar, P.; Reddy, V. Glycoproteome of elongating cotton fibre cells. Mol. Cell. Proteomics 2013, 12, 3677-3789. [CrossRef] [PubMed]

51. Minic, Z.; Jamet, E.; Negroni, L.; Der Garabedian, P.A.; Zivy, M.; Jouanin, L. A sub-proteome of Arabidopsis thaliana trapped on Concanavalin A is enriched in cell wall glycoside hydrolases. J. Exp. Bot. 2007, 58, 2503-2512. [CrossRef] [PubMed]

52. Borner, G.H.H.; Lilley, K.S.; Stevens, T.J.; Dupree, P. Identification of glycosylphosphatidylinositol-anchored proteins in Arabidopsis. A proteomic and genomic analysis. Plant Physiol. 2003, 132, 568-577. [CrossRef] [PubMed]

53. Borner, G.H.H.; Sherrier, D.J.; Weimar, T.; Mchaelson, L.V.; Hawkins, N.D.; MacAskill, A.; Napier, J.A.; Beale, M.H.; Lilley, K.S.; Dupree, P. Analysis of detergent-resistant membranes in Arabidopsis: Evidence for plasma membrane lipid rafts. Plant Physiol. 2005, 137, 104-116. [CrossRef] [PubMed]

54. Marmagne, A.; Ferro, M.; Meinnel, T.; Bruley, C.; Kuhn, L.; Garin, J.; Barbier-Brygoo, H.; Ephritikhine, G. A high content in lipid-modified peripheral proteins and integral receptor kinases features in the Arabidopsis plasma membrane proteome. Mol. Cell. Proteomics 2007, 6, 1980-1996. [CrossRef] [PubMed]

55. Komatsu, S.; Wada, T.; Yann, A.; Nouri, M.Z.; Nanjo, Y.; Nakayama, N.; Shimamura, S.; Yamamoto, R.; Nakamura, T.; Furukawa, K. Analysis of plasma membrane proteome in soybean and application to flooding stress response. J. Proteome Res. 2009, 8, 4487-4499. [CrossRef] [PubMed]

56. Rose, J.K.C.; Lee, S.J. Straying off the highway: Trafficking of secreted plant proteins and complexity in the plant cell wall proteome. Plant Physiol. 2010, 153, 433-436. [CrossRef] [PubMed]

57. Feiz, L.; Irshad, M.; Pont-Lezica, R.F.; Canut, H.; Jamet, E. Evaluation of cell wall preparations for proteomics: A new procedure for purifying cell walls from Arabidopsis hypocotyls. Plant Methods 2006, 2, 10. [CrossRef] [PubMed]

58. Kong, F.J.; Oyanagi, A.; Komatsu, S. Cell wall proteome of wheat roots under flooding stress using gel-based and LC MS/MS-based proteomics approaches. Biochim. Biophys. Acta 2010, 1804, 124-136. [CrossRef] [PubMed]

59. Pardo, M.; Ward, M.; Bains, S.; Molina, M.; Blackstock, W.; Gil, C.; Nobela, C. A proteomic approach for the study of Saccharomyces cerevisiae cell wall biogenesis. Electrophoresis 2000, 21, 3396-3410. [CrossRef]

60. Pitarch, A.; Sanchez, M.; Nombela, C.; Gil, C. Sequential fractionation and two-dimensional gel analysis unravels the complexity of the dimorphic fungus Candida albicans cell wall proteome. Mol. Cell. Proteomics 2002, 1, 967-982. [CrossRef] [PubMed]

61. Pitarch, A.; Nombela, C.; Gil, C. Cell wall fractionation for yeast and fungal proteomics. Methods Mol. Biol. 2008, 425, 217-239. [CrossRef] [PubMed]

62. Yokoyama, R.; Nishitani, K. Genomic basis for cell-wall diversity in plants. A comparative approach to gene families in rice and Arabidopsis. Plant Cell Physiol. 2004, 45, 1111-1121. [CrossRef] [PubMed]

63. Manza, L.L.; Stamer, S.L.; Ham, A.L.; Codreanu, S.G.; Liebler, D.C. Sample preparation and digestion for proteomic analyses using spin filters. Proteomics 2005, 5, 1742-1745. [CrossRef] [PubMed]

64. Kitazawa, K.; Tryfona, T.; Yoshimi, Y.; Hayashi, Y.; Kawauchi, S.; Antonov, L.; Tanaka, H.; Takahashi, T.; Kaneko, S.; Dupree, P.; Tsumuraya, Y.; Kotake, T. $\beta$-Galactosyl Yariv reagent binds to the $\beta$-1,3-galactan of arabinogalactan proteins. Plant Physiol. 2013, 161, 1117-1126. [CrossRef] [PubMed] 
65. Schultz, C.J.; Ferguson, K.L.; Lahnstein, J.; Bacic, A. Posttranslational modifications of arabinogalactan-peptides of Arabidopsis thaliana. Endoplasmic reticulum and glycosylphosphatidylinositol-anchor signal cleavage sites and hydroxylation of proline. J. Biol. Chem. 2004, 279, 45503-45511. [CrossRef] [PubMed]

66. Graumann, J.; Dunipace, L.A.; Seol, J.H.; McDonald, W.H.; Yates, J.R., III; Wold, B.J.; Deshaies, R.J. Applicability of tandem affinity purification MudPIT to pathway proteomics in yeast. Mol. Cell. Proteomics 2004, 3, 226-237. [CrossRef] [PubMed]

67. Wang, Y.; Mortimer, J.C.; Davis, J.; Dupree, P.; Keegstra, K. Identification of an additional protein involved in mannan biosynthesis. Plant J. 2013, 73, 105-117. [CrossRef] [PubMed]

68. Ogasawara, K.; Yamada, K.; Christeller, J.T.; Kondo, M.; Hatsugai, N.; Hara-Nishimura, I.; Nishimura, M. Constitutive and inducible ER bodies of Arabidopsis thaliana accumulate distinct beta-glucosidases. Plant Cell Physiol. 2009, 50, 480-488. [CrossRef] [PubMed]

69. Lewis, D.R.; Olex, A.L.; Lundy, S.R.; Turkett, W.H.; Fetrow, J.S.; Muday, G.K. A kinetic analysis of the auxin transcriptome reveals cell wall remodeling proteins that modulate lateral root development in Arabidopsis. Plant Cell 2013, 25, 3329-3346. [CrossRef] [PubMed]

70. Yokoyama, R.; Uwagaki, Y.; Sasaki, H.; Harada, T.; Hiwatashi, Y.; Hasebe, M.; Nishitani, K. Biological implications of the occurrence of 32 members of the XTH (xyloglucan endotransglucosylase/hydrolase) family of proteins in the bryophyte Physcomitrella patens. Plant J. 2010, 64, 658-669. [CrossRef] [PubMed]

71. Takenaka, Y.; Nakano, S.; Tamoi, M.; Sakuda, S.; Fukamizo, T. Chitinase gene expression in response to environmental stresses in Arabidopsis thaliana: Chitinase inhibitor allosamidin enhances stress tolerance. Biosci. Biotechnol. Biochem. 2009, 73, 1066-1071. [CrossRef] [PubMed]

72. Cao, J. The pectin lyases in Arabidopsis thaliana: Evolution, selection and expression profiles. PLoS ONE 2012, 7, e46944. [CrossRef] [PubMed]

73. Ferrari, S.; Sella, L.; Janni, M.; De Lorenzo, G.; Favaron, F.; D'Ovidio, R. Transgenic expression of polygalacturonase-inhibiting proteins in Arabidopsis and wheat increases resistance to the flower pathogen Fusarium graminearum. Plant Biol. 2012, 14, 31-38. [CrossRef] [PubMed]

74. Günl, M.; Pauly, M. AXY3 encodes a $\alpha$-xylosidase that impacts the structure and accessibility of the hemicellulose xyloglucan in Arabidopsis plant cell walls. Planta 2011, 233, 707-719. [CrossRef] [PubMed]

75. Mazola, Y.; Guirola, O.; Palomares, S.; Chinea, G.; Menéndez, C.; Hernández, L.; Musacchio, A. A comparative molecular dynamics study of thermophilic and mesophilic $\beta$-fructosidase enzymes. J. Mol. Model. 2015, 21, 228. [CrossRef] [PubMed]

76. Sampedro, J.; Gianzo, C.; Iglesias, N.; Guitián, E.; Revilla, G.; Zarra, I. AtBGAL10 is the main xyloglucan $\beta$-galactosidase in Arabidopsis, and its absence results in unusual xyloglucan subunits and growth defects. Plant Physiol. 2012, 158, 1146-1157. [CrossRef] [PubMed]

77. Lombard, V.; Golaconda Ramulu, H.; Drula, E.; Coutinho, P.M.; Henrissat, B. The Carbohydrate-active enzymes database (CAZy) in 2013. Nucl. Acids Res. 2014, 42, D490-D495. [CrossRef] [PubMed]

78. Obayashi, T.; Kinoshita, K.; Nakai, K.; Shibaoka, M.; Hayashi, S.; Saeki, M.; Shibata, D.; Saito, K.; Ohta, H.; et al. ATTED-II: A database of co-expressed genes and cis elements for identifying co-regulated gene groups in Arabidopsis. Nucl. Acids Res. 2007, 35, D863-D869. [CrossRef] [PubMed]

79. Obayashi, T.; Hayashi, S.; Saeki, M.; Ohta, H.; Kinoshita, K. ATTED-II provides coexpressed gene networks for Arabidopsis. Nucl. Acids Res. 2009, 37, D987-D991. [CrossRef] [PubMed]

80. Arabidopsis Interactome Mapping Consortium. Evidence for Network Evolution in an Arabidopsis Interactome Map. Science 2011, 333, 601-607. [CrossRef]

81. Yokoyama, R.; Nishitani, K. Functional diversity of xyloglucan-related proteins and its implications in the cell wall dynamics in plants. Plant Biol. 2000, 2, 598-604. [CrossRef]

82. Yokoyama, R.; Nishitani, K. A comprehensive expression analysis of all members of a gene family encoding cell-wall enzymes allowed us to predict cis-regulatory regions involved in cell-wall construction in specific organs of Arabidopsis. Plant Cell Physiol. 2001, 42, 1025-1033. [CrossRef] [PubMed]

83. Eklöf, J.M.; Brumer, H. The XTH gene family: An update on enzyme structure, function, and phylogeny in xyloglucan remodeling. Plant Physiol. 2010, 153, 456-466. [CrossRef] [PubMed]

84. Nishitani, K.; Tominaga, R. Endoxyloglucan transferase, a novel class of glycosyltransferase that catalyzes transfer of a segment of xyloglucan molecule to another xyloglucan molecule. J. Biol. Chem. 1992, 267, 21058-21064. [PubMed] 
85. Fry, S.C.; Smith, R.C.; Renwick, K.F.; Martin, D.J.; Hodge, S.K.; Matthews, K.J. Xyloglucan endotransglycosylase, a new wall-looseniing enzyme activity from plants. Biochem. J. 1992, 282, 821-828. [CrossRef] [PubMed]

86. Nishitani, K. The role of endoxyloglucan transferase in the organization of plant cell wall. Int. Rev. Cytol. 1997, 173, 157-206. [CrossRef] [PubMed]

87. Rose, J.K.C.; Braam, J.; Fry, S.; Nishitani, K. The XTH family of enzymes involved in xyloglucan endotransglucosylation and endohydrolysis: Current perspectives and a new unifying nomenclature. Plant Cell Physiol. 2002, 43, 1421-1435. [CrossRef] [PubMed]

88. Nishitani, K. A brief history of the XTH gene family. In The Science and Lore of the Plant Cell Wall; Hayashi, T., Ed.; Brown Walker Press: Boca Raton, FL, USA, 2006; pp. 148-154.

89. Sampedro, J.; Sieiro, C.; Revilla, G.; Gonzalez-Villa, T.; Zarra, I. Cloning and expression pattern of a gene encoding an $\alpha$-xylosidase active against xyloglucan oligosaccharides from Arabidopsis. Plant Physiol. 2001, 126, 910-920. [CrossRef] [PubMed]

90. Kaida, R.; Serada, S.; Norioka, N.; Norioka, S.; Neumetzler, L.; Pauly, M.; Sampedro, J.; Zarra, I.; Hayashi, T.; Kaneko, T.S. Potential role for purple acid phosphatase in the dephosphorylation of wall proteins in tobacco cells. Plant Physiol. 2010, 153, 603-610. [CrossRef] [PubMed]

91. Kaida, R.; Sugawara, S.; Negoro, K.; Maki, H.; Hayashi, T.; Kaneko, T.S. Acceleration of cell growth by xyloglucan oligosaccharides in suspension-cultured tobacco cells. Mol. Plant 2010, 3, 549-554. [CrossRef] [PubMed]

92. Hayashi, T.; Kaida, R. Functions of xyloglucan in plant cells. Mol. Plant 2011, 4, 17-24. [CrossRef] [PubMed]

93. Nishitani, K.; Vissenberg, K. Roles of the XTH protein family in the expanding cell. In The Expanding Cell; Verbelen, J.-P., Vissenberg, K., Eds.; Springer-Verlag: Vienna, Austria, 2006; pp. 89-116.

94. Yokoyama, R.; Nishitani, K. Endoxyloglucan transferase is localized both in the cell plate and in the secretory pathway destined for the apoplast in tobacco cells. Plant Cell Physiol. 2001, 42, 292-300. [CrossRef] [PubMed]

95. Yokoyama, R.; Tanaka, D.; Fujino, T.; Itoh, T.; Nishitani, K. Cell Wall Dynamics in Tobacco BY-2 Cells. In Biotechnology in Agriculture and Forestry; Nagata, T., Hasezawa, S., Inzé, D., Eds.; Springer-Verlag: Vienna, Austria, 2003; Volume 53, pp. 217-230.

96. Moore, P.J.; Darvill, A.G.; Albersheim, P.; Staehelin, A.S. Immunogold localization of xyloglucan and rhamnogalacturonan I in the cell walls of suspension-cultured sycamore cells. Plant Physiol. 1986, 82, 787-794. [CrossRef] [PubMed]

97. Otegui, M.; Andrew Staehelin, A. Syncytial-type cell plates: A novel kind of cell plate involved in endosperm cellularization of Arabidopsis. Plant Cell 2000, 12, 933-947. [CrossRef] [PubMed]

98. Sonobe, S.; Nakayama, N.; Shimmen, T.; Sone, Y. Intracellular distribution of subcellular organelles revealed by antibody against xyloglucan during cell cycle in tobacco BY-2 cells. Protoplasma 2000, 213, 218-227. [CrossRef]

99. Albenne, C.; Canut, H.; Jamet, E. Plant cell wall proteomics: The leadership of Arabidopsis thaliana. Front. Plant Sci. 2013, 4, 111. [CrossRef] [PubMed]

100. Albenne, C.; Canut, H.; Hoffmann, L.; Jamet, E. Plant cell wall proteins: A large body of data, but what about runaways? Proteomes 2014, 2, 224-242. [CrossRef]

101. Guerra-Guimarães, L.; Pinheiro, C.; Chaves, I.; Barros, D.R.; Ricardo, C.P. Protein dynamics in the plant extracellular space. Proteomes 2016, 4, 22. [CrossRef]

102. Clemente, H.S.; Jamet, E. WallProtDB, a database resource for plant cell wall proteomics. Plant Methods 2015, 11, 2. [CrossRef] [PubMed]

103. Sarkar, P.; Bosneaga, E.; Auer, M. Plant cell walls throughout evolution: Towards a molecular understanding of their design principles. J. Exp. Bot. 2009, 60, 3615-3635. [CrossRef] [PubMed]

104. Popper, Z.A.; Michel, G.; Hervé, C.; Domozych, D.S.; Willats, W.G.; Tuohy, M.G.; Kloareg, B.; Stengel, D.B. Evolution and diversity of plant cell walls: From algae to flowering plants. Annu. Rev. Plant. Biol. 2011, 62, 567-590. [CrossRef] [PubMed]

105. Fangel, J.U.; Ulvskov, P.; Knox, J.P.; Mikkelsen, M.D.; Harholt, J.; Popper, Z.A.; Willats, W.G.T. Cell wall evolution and diversity. Front. Plant Sci. 2012, 3, 152. [CrossRef] [PubMed]

106. Yokoyama, R.; Narukawa, H.; Nishitani, K. Disclosing two typical cell wall polysaccharides, pectin and $\beta-1,3 / 1,4$ mixed linked glucan, individually by immunological localization in two angiosperms, Arabidopsis thaliana and Oryza sativa. In Atlas of Plant Cell Structure; Noguchi, T., Kawano, S., Tsukaya, H., Matsunaga, S., Sakai, A., Karahara, I., Hayashi, Y., Eds.; Springer-Verlag: Vienna, Austria, 2014; pp. 150-151. 
107. Yokoyama, R.; Rose, J.K.C.; Nishitani, K. A surprising diversity and abundance of xyloglucan endotransglucosylase/hydrolases in rice. Classification and expression analysis. Plant Physiol. 2004, 134, 1088-1099. [CrossRef] [PubMed]

108. Hara, Y.; Yokoyama, R.; Osakabe, K.; Toki, S.; Nishitani, K. Function of xyloglucan endotransglucosylase/hydrolases in rice. Ann. Bot. 2014, 114, 1309-1318. [CrossRef] [PubMed]

(c)

(C) 2016 by the authors; licensee MDPI, Basel, Switzerland. This article is an open access article distributed under the terms and conditions of the Creative Commons Attribution (CC-BY) license (http://creativecommons.org/licenses/by/4.0/). 